\title{
The role of RASSF1A methylation in cancer
}

\author{
Luke B. Hesson ${ }^{\mathrm{a}, \mathrm{b}}$, Wendy N. Cooper ${ }^{\mathrm{a}}$ and Farida Latif ${ }^{\mathrm{a}, *}$ \\ ${ }^{a}$ Section of Medical and Molecular Genetics, Division of Reproductive and Child Health, Institute of Biomedical \\ Research, University of Birmingham, Edgbaston, Birmingham, UK \\ ${ }^{\mathrm{b}}$ MRC Protein Phosphorylation Unit, School of Life Sciences, MSI/WTB Complex, Dow Street, University of \\ Dundee, Dundee, Scotland, UK
}

\begin{abstract}
Tumour suppressor gene inactivation is critical to the pathogenesis of cancers; such loss of function may be mediated by irreversible processes such as gene deletion or mutation. Alternatively tumour suppressor genes may be inactivated via epigenetic processes a reversible mechanism that promises to be more amenable to treatment by therapeutic agents. The CpG dinucleotide is under-represented in the genome, but it is found in clusters within the promoters of some genes, and methylation of these $\mathrm{CpG}$ islands play a critical role in the control of gene expression. Inhibitors of the DNA methyltransferases DNMT1 and DNMT3b have been used in a clinical setting, these nucleotide analogues lack specificity but the side effects of low dose treatments were minimal and in 2004 Vidaza (5-azacitidine) was licensed for use in myelodysplastic syndrome. Methylation inhibitors are also entering trials in conjunction with another class of epigenetic modifiers, the histone deacetylase inhibitors and this epigenetic double bullet offers hope of improved treatment regimes. Recently there has been a plethora of reports demonstrating epigenetic inactivation of genes that play important roles in development of cancer, including Ras-association domain family of genes. Epigenetic inactivation of RASSF1A (Ras-association domain family 1, isoform A) is one of the most common molecular changes in cancer. Hypermethylation of the RASSF1A promoter CpG island silences expression of the gene in many cancers including lung, breast, prostate, glioma, neuroblastoma and kidney cancer. Several recent studies have illustrated the diagnostic and prognostic potential of RASSF1A methylation. This presents RASSF1A methylation as an attractive biomarker for early cancer detection which, for most cancers, results in improved clinical outcome. DNA methylation analysis is applicable to a range of body fluids including serum, urine, bronchioalveolar lavage and sputum. The ease with which these body fluids can be acquired negates the need for invasive procedures to obtain biopsy material. This review will discuss the feasibility of using RASSF1A methylation as a diagnostic and prognostic marker in cancer management.
\end{abstract}

Keywords: RASSF1A, tumour suppressor gene, 3p21.3, ras association domain, methylation, cancer

\section{Introduction}

Cancer mortality could be greatly reduced by earlier detection since existing surgical and treatment strategies are more effective against early stage tumours. In the case of lung cancer around two-thirds of patients present with advanced metastatic tumours at the time of diagnosis [125]. This is also true for ovarian cancer patients $70 \%$ of whom have advanced disease (stage III

${ }^{*}$ Corresponding author: F. Latif, Section of Medical and Molecular Genetics, Division of Reproductive and Child Health, Institute of Biomedical Research, University of Birmingham, Edgbaston, Birmingham, UK. Tel.: +44 121627 2741; Fax: +44 121627 2618; E-mail: f.latif@bham.ac.uk. or IV) and 5 year survival of only 15-20\% upon presentation [57]. DNA methylation has several advantages over commonly used biomarkers such as cytology or the assay of tumour-derived RNA or protein. DNA methylation is a molecular change more readily detectable than gross cytogenetic or cellular abnormalities which can also be subjective. Other techniques such as radiography rely on a visible tumour mass, which can make them unsuitable for early detection. Some screening strategies rely on the detection of tumour-derived RNA or protein. However, DNA is much more stable and unlike protein can be amplified for increased sensitivity and is not dependent on levels of gene expression. This also makes the use of DNA more suitable when a limited amount of tissue/fluid is available. DNA methyla- 
tion associated with particular genes is one of the earliest detectable changes and in some cases may even precede tumour-formation. DNA methylation may also provide prognostic information. Furthermore, tumourassociated hypermethylation usually occurs in discrete $\mathrm{CpG}$ island promoter regions. This minimises the region of analysis when compared to mutation screening involving several exons. Since DNA methylation is heritable, a gene that acquires methylation will usually remain methylated throughout tumour progression. Finally, some cancer biomarkers such as allelic loss, experimentally rely on loss of signal as opposed to DNA methylation which is gain of signal $[88,124]$.

A further advantage of DNA methylation analysis is its applicability to a range of body fluids. The presence of tumour-derived DNA within the blood stream (either within tumour cells or as free DNA) has been known for some time [73]. Tumour DNA within the bloodstream arises following vascular invasion or absorption of DNA from apoptotic or necrotic cells at the tumour site. Tumour-derived DNA may also be found in bodily fluids that drain from the organ of interest including urine, bronchioalveolar lavage, nipple aspirates, mouth and throat rinsings, nasopharyngeal swabs and stool samples. The ease with which body fluids can be acquired negates the need for invasive procedures to obtain biopsy material. A range of techniques are available to study DNA methylation. These include CoBRA (Combined Bisulphite Restriction Analysis) and bisulphite sequencing, methylation-specific PCR (MSP) and high throughput quantitative MethyLight assays [34,48,116,129].

Recently we and others have cloned and characterised the RASSF 1 gene and shown frequent inactivation of the $\mathrm{A}$ isoform by promoter $\mathrm{CpG}$ island hypermethylation in a broad spectrum of tumour types. Several studies reveal that $R A S S F 1 A$ methylation can also be detected in several body fluids in cancer patients highlighting its potential as a disease marker.

\section{RASSF1A inactivation in cancer}

Allelic losses of $3 p$ are one of the most frequently detected genetic alterations in many cancers including lung, kidney and breast cancers. Loss of heterozygosity studies and the identification of overlapping homozygous deletions in lung and breast tumour cell lines indicated a critical region at 3 p21.3 that may harbour one or more tumour suppressor genes (TSGs). Eight genes, namely CACNA2D2, PL6/Placental protein
6, 101F6, TUSC4/NPRL2, ZMYND10/BLU, RASSF1, TUSC2/FUS1 and HYAL2 were cloned from the minimal $120 \mathrm{~kb}$ overlapping region. Despite extensive investigation only rare mutations and polymorphisms of those genes were identified. Interestingly however, expression of RASSF1A, but not its alternative splice form RASSF1C, was lost or downregulated in most lung tumour cell lines [26,74]. The principal cause of this loss of expression was promoter CpG island hypermethylation. The Ras-association domain family member 1 (RASSF 1) gene is comprised of eight exons and generates seven transcripts, designated RASSF1A$\mathrm{G}$, via differential promoter usage and alternative splicing. Two major isoforms RASSF1A and RASSF1C, are transcribed from two separate $\mathrm{CpG}$ island promoter regions (See figure 1a). Both RASSF1A and RASSF1C proteins contain a C-terminal Ras-association domain and a putative ATM phosphorylation site. In addition to this RASSF1A also contains an N-terminal diacylglycerol binding/protein kinase $\mathrm{C}$ conserved 1 (C1) domain. RASSF 1A inactivation by methylation was originally described in lung and breast cancers [26]. Since then it has emerged that RASSF1A is one of the most frequently hypermethylated genes so far described in human cancer. Inactivation is frequently observed in a broad spectrum of tumours (summarised in Table 1 and Fig. 2). Associated loss of expression has been shown in lung, breast, bladder, gastric, cholangiocarcinoma and oesophageal sqaumous cell carcinoma primary tumours $[12,13,26,67,70,126]$. While allelic loss at the RASSF1 locus has been shown to be a frequent 'second hit' $[3,5,67,85]$, mutation is described as an occasional event $[3,26,68,74,80]$. Recently however, using a more sensitive methodology a high incidence of RASSF1A mutations were found in primary NPC tumours [93]. In some cases, such as in medulloblastoma, biallelic inactivation of RASSF1A by promoter hypermethylation has been observed [80].

\section{Human homologues of RASSF1}

Homology searches of the human genome have identified several other members of the RASSF gene family that also contain a Ras-association domain. These are RASSF2 (20pter-p12.1), RASSF3 (12q14.1), RASSF4/AD037(10p11.21), RASSF5/NORE1 (1q32.1) and RASSF6 (4q21.21), (Fig. 1b). Interestingly some of these additional members are also inactivated by promoter hypermethylation. Tumour-specific RASSF2 promoter hypermethylation frequently inactivates 
Table 1

RASSF1A methylation occurs in a broad spectrum of tumours. Frequencies (given as percentages) can differ significantly between tumour types

Cancer

RASSF1A methylation

Percentage of RASSF1A Reference methylation in

Anal SCC

primary tumours

Bladder

$35(34 / 98)$

$48(19 / 40) \quad[15]$

$51(23 / 45)$

Breast

$62(28 / 45)$

$49(19 / 39) \quad$ [12]

$65(11 / 17)$

Biliary tract

$27(10 / 37)$

Cervical SCC

$30(10 / 33)$

[134]

$10(4 / 42) \quad$ [69]

$0(0 / 31)$

Cervical adenosqaumous

$21(4 / 19)$

Cervical adenocarcinoma

$12(2 / 17)$

$24(8 / 34)$

[69]

$45(9 / 20)$

Cholangiocarcinoma

$69(9 / 13)$

[126]

$65(47 / 72) \quad$ [131]

$85(28 / 33)$

Colorectal

$20(45 / 222)$

$45(13 / 29) \quad$ [122]

$16(24 / 149) \quad$ [71]

Ependymoma

Esophageal SCC

$24(13 / 55) \quad[130]$

Ewing's sarcoma

Gastric EBV+

$[46]$

Gastric EBV-

Gastric

Glioma

$4(2 / 56)$

$43(39 / 90)$

$57(36 / 63)$

$54(25 / 46)$

$57(12 / 21)$

$57(16 / 28)$

$0(0 / 32)$

$15(7 / 46)$

$17(2 / 24)$

$8(6 / 80)$

$12(5 / 42)$

$19(5 / 27)$

Hepatoblastoma

$85(70 / 83)$

$100(29 / 29)$

[60]

Hepatocellular

$95(41 / 43)$

$65(34 / 52)$

Hodgkin's lymphoma

Kidney

$91(39 / 43)$

$26(44 / 165)$

$46(23 / 50)$

Lung: SCLC

$72(21 / 29)$

$79(22 / 28)$

Lung: NSCLC

$84(36 / 43)$

$34(14 / 41)$

$30(32 / 107)$

$32(35 / 110)$

$15(3 / 20)$

Leukaemia (acute)

$79(27 / 34)$

[13]

[56]

[7]

[97]

[81]

[29]

[52]

[47]

[91]

[46]

[136]

[133]

[137]

[89]

[30]

[85]

[32]

[3]

[28]

[114]

[3]

[12]

[111]

Medulloblastoma

[80] 


\begin{tabular}{|c|c|c|}
\hline \multirow[t]{2}{*}{ Cancer } & \multicolumn{2}{|c|}{ RASSF1A methylation } \\
\hline & $\begin{array}{c}\text { Percentage of RASSF1A } \\
\text { methylation in } \\
\text { primary tumours }\end{array}$ & Reference \\
\hline \multirow[t]{2}{*}{ Melanoma } & $41(14 / 44)$ & [108] \\
\hline & $15(3 / 20)$ & {$[55]$} \\
\hline Meningioma & $17(2 / 12)$ & [56] \\
\hline Mesothelioma & $32(21 / 66)$ & [113] \\
\hline \multirow[t]{3}{*}{ Multiple myeloma } & $28(9 / 32)$ & [90] \\
\hline & $15(17 / 113)$ & [104] \\
\hline & $0(0 / 56)$ & [44] \\
\hline \multirow[t]{2}{*}{ Nasopharyngeal } & $67(20 / 30)$ & {$[16]$} \\
\hline & $67(14 / 21)$ & [79] \\
\hline \multirow[t]{3}{*}{ Neuroblastoma } & $55(37 / 67)$ & {$[5]$} \\
\hline & $52(14 / 27)$ & {$[46]$} \\
\hline & $84(26 / 31)$ & {$[8]$} \\
\hline Osteosarcoma & $0(0 / 11)$ & [46] \\
\hline \multirow[t]{3}{*}{ Ovarian } & $40(8 / 20)$ & {$[132]$} \\
\hline & $50(25 / 50)$ & [57] \\
\hline & $41(20 / 49)$ & [98] \\
\hline Pancreatic & $62(47 / 75)$ & [27] \\
\hline Phaeochromocytoma & $22(5 / 23)$ & [5] \\
\hline Pituitary adenoma & $28(20 / 52)$ & [95] \\
\hline $\begin{array}{l}\text { Primitive neuroectodermal } \\
\text { tumours (supratentorial) }\end{array}$ & $79(19 / 24)$ & [86] \\
\hline \multirow[t]{3}{*}{ Prostate } & $54(53 / 101)$ & {$[83]$} \\
\hline & $71(37 / 52)$ & [78] \\
\hline & $99(117 / 118)$ & [59] \\
\hline Rhabdomyosarcoma & $61(11 / 18)$ & [46] \\
\hline \multirow{2}{*}{ Retinoblastoma } & $59(10 / 17)$ & [46] \\
\hline & $82(56 / 68)$ & [23] \\
\hline $\begin{array}{l}\text { Salivary gland adenoid cys- } \\
\text { tic carcinoma }\end{array}$ & $40(25 / 60)$ & [76] \\
\hline Schwannoma & $10(1 / 10)$ & {$[56]$} \\
\hline \multirow[t]{2}{*}{ Testicular nonseminoma } & $83(15 / 18)$ & [54] \\
\hline & $21(9 / 44)$ & [64] \\
\hline Testicular seminoma & $40(4 / 10)$ & [54] \\
\hline \multirow[t]{2}{*}{ Thyroid } & $71(27 / 38)$ & {$[102]$} \\
\hline & $37(19 / 51)$ & [128] \\
\hline \multirow[t]{2}{*}{ Wilms' tumour } & $71(22 / 31)$ & [36] \\
\hline & $54(21 / 39)$ & {$[122]$} \\
\hline
\end{tabular}

RASSF2A expression in colorectal carcinomas at frequencies ranging from $42 \%$ to $70 \%$. Furthermore, in colorectal carcinoma RASSF $2 A$ inactivation is an early event detectable in adenoma polyps [4,51]. Inactivation of RASSF $2 A$ in colorectal carcinomas is a much earlier and more frequent event than inactivation of RASSFIA (15-45\%; [4,51,117,122]). Hence, RASSF2 methylation may provide a much more effective marker for early detection and diagnosis of colorectal carcinomas. RASSF 2 methylation has also been found in gastric cancer at frequencies ranging from $29 \%$ to $79 \%$ [38]. Whilst RASSF4/AD037 is expressed in a variety of normal tissues, it is lost or downregulated in a variety of tumour cell lines and primary tumours. In some cases this loss of expression is caused by promoter hypermethylation $[22,35]$. Expression of NORE1A, but

not NORE1B, is lost or downregulated in cancer due to promoter hypermethylation, whilst mutation of the NORE 1 gene is a rare event [17,50,58]. RASSF3A is not methylated in human tumours [4,49,51], and RASSF6 is not methylated in colorectal cancer [4].

\section{RASSF1A function}

Recent investigation of RASSF1A has revealed a protein with diverse functions including the regulation of apoptosis and of microtubule dynamics during mitotic progression. Re-expression of RASSF1A also suppresses growth in in vitro and in vivo systems in lung, breast, kidney, prostate, NPC and glioma cancer cells $[12,21,26,30,49,68]$. Overexpression of 


\section{a) RASSF1 gene locus and major transcripts}

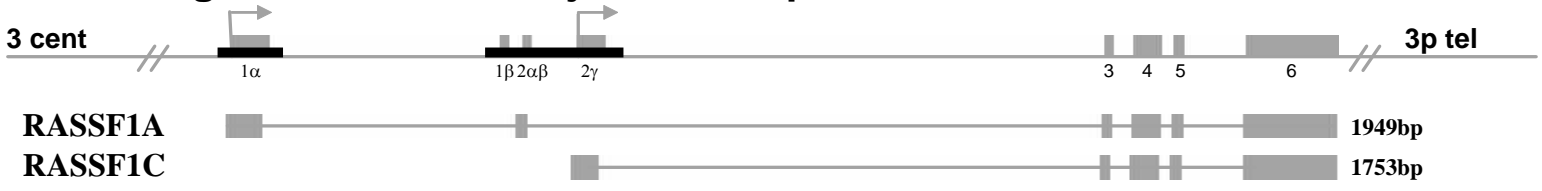

\section{b) RASSF family proteins}

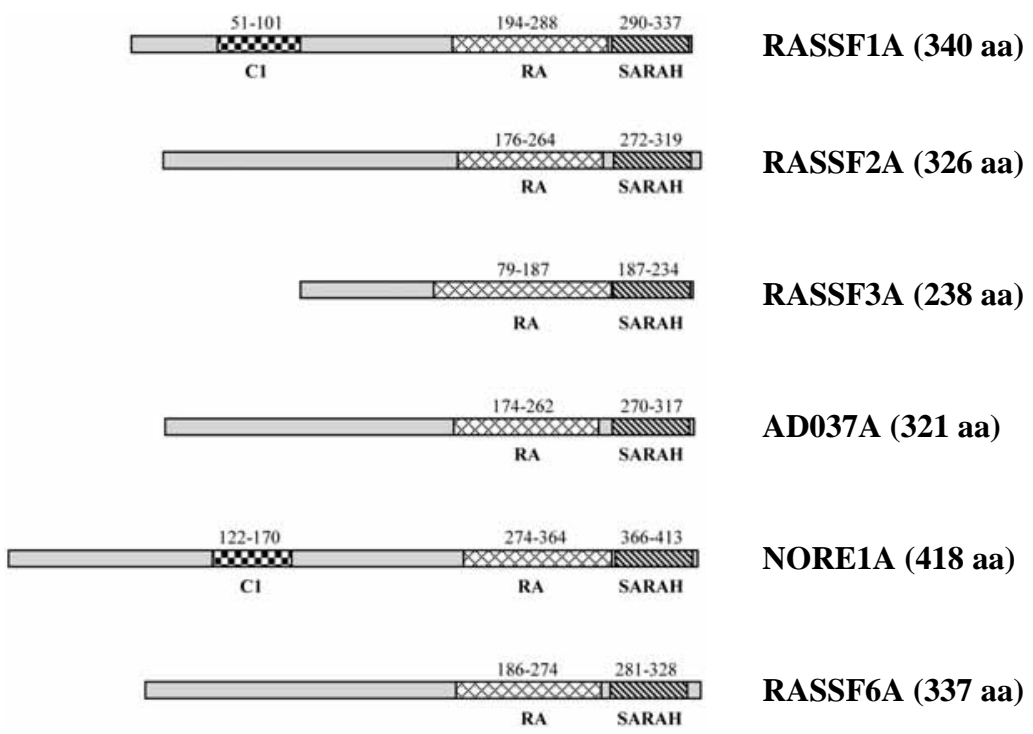

Fig. 1. a) The RASSF1 gene locus and major transcripts. RASSF1 isoforms are generated by differential promoter usage (arrows) and alternative splicing. The two promoter associated $\mathrm{CpG}$ islands are shown in black, and the major transcripts associated with these promoters are also depicted. b) The domain structures of the A isoforms of the RASSF family of proteins. Putative functional domains (predicted using Prosite) of RASSF1 (AAD44174), RASSF2 (AAN59975), RASSF3 (AAO61687), AD037 (AAH32593), NORE1 (NP 872604) and RASSF6 (NP 803876) are shown: RA, RalGDS/AF6 Ras association domain; C1, DAG/diacylglycerol binding domain; and SARAH, Sav/RASSF/Hpo interaction domain.

RASSF1A results in cell cycle arrest and is accompanied by dramatic changes in gene expression $[1$, 20]. This includes changes to the expression of important cell cycle regulatory genes such as cyclin D [105] but also to genes involved in diverse functions including transcription, cytoskeletal organisation, angiogenesis, signalling, cell adhesion, cell migration and apoptosis. RASSF1A regulates apoptosis via at least two pathways. RASSF1A binds the proapoptotic serine/threonine kinase MST1 [62]. NORE1A and RASSF1A are constitutively complexed with MST1 and serve as sensory modules to detect pro-apoptotic signals initiated through Ras pathways [62,94]. Although RASSF2, NORE1/RASSF5 and AD037/RASSF4 bind to Ras proteins directly RASSF1A associates with K-Ras indirectly through NORE1A [35,92,118,119,121]. The RASSF1A-MST1 complex may also indirectly associate with Ras via
CNK1 [96]. RASSF1A may also regulate apoptosis through MOAP-1 (Modulator of Apoptosis 1). MOAP1 associates with Bcl-2 family members Bax and Bcl-2 and initiates caspase-dependent apoptosis when overexpressed [109]. Following apoptotic stimulation, RASSF1A associates with MOAP-1, promoting Bax conformational change, integration of Bax into the mitochondrial membrane and the release of cytochromec. In support of this, the effects of RASSF1A on Bax conformation were reversed by siRNA directed against RASSF1A [6]. RASSF1A is also involved in the regulation of cytoskeletal dynamics and colocalises with microtubules, spindles and centrosomes during metaphase and promotes microtubule stability and polymerisation $[25,77,120]$. RASSF1A microtubule association may be mediated in part by interaction with MAP1B and C19ORF5 [25]. RASSF1A also binds Cdc20, which negatively regulates APC 


\section{Frequency of RASSF1A methylation in cancer}

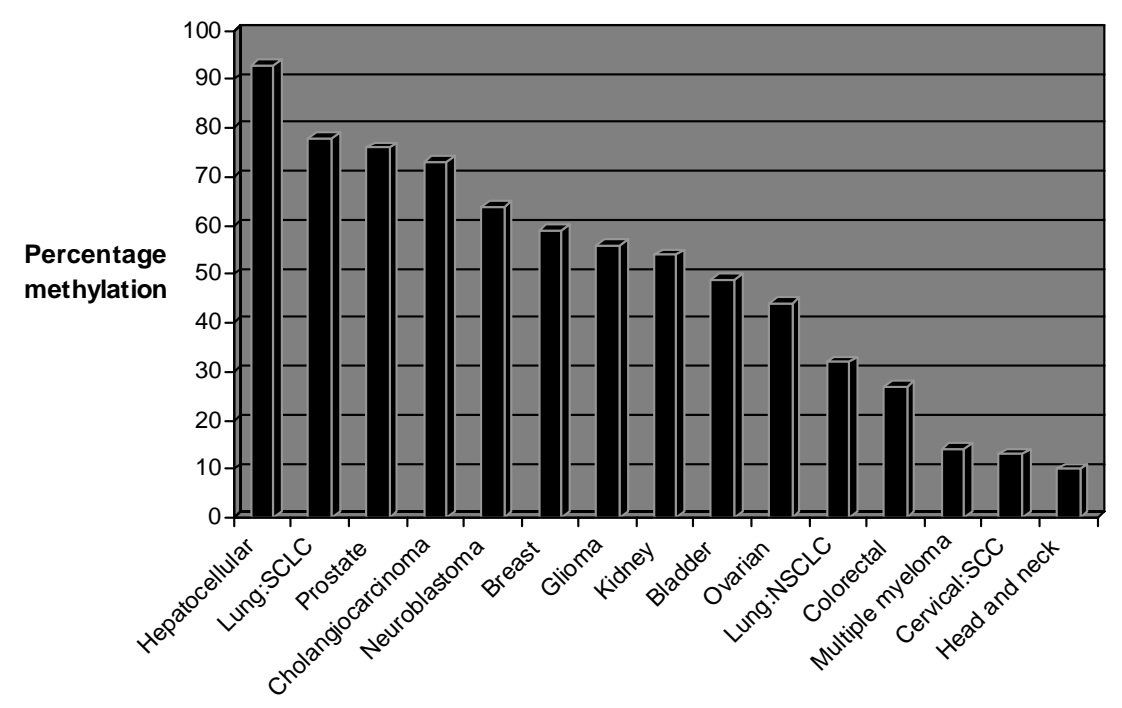

Fig. 2. Frequency of RASSF1A methylation in several tumour types. Several of the most common cancers are shown. Frequencies represent the average of at least three independent studies on a given tumour type (see Table 1).

(anaphase promoting complex). The Cdc20-APC complex is a central component of the spindle assembly checkpoint during mitosis [107]. RASSF1A can also inhibit $\mathrm{G}_{1}-\mathrm{S}$ phase transition by interacting with p120 $0^{\mathrm{E} 4 \mathrm{~F}}$, a protein known to associate with $\mathrm{pRb}, \mathrm{p} 53$ and $14{ }^{A R F}[39,40,99,101]$. For a more extensive review of RASSF1 functions, see [2].

\section{RASSF1A methylation as a cancer biomarker}

Methylation of RASSF1A seems an ideal cancer biomarker for three main reasons. Firstly, methylation occurs in a very broad spectrum of tumour types. Secondly, the frequency of methylation is often moderate to very high (Table 1 ) thus providing a high frequency of diagnostic coverage. Thirdly, methylation of RASSF 1A is rare in normal tissues providing a marker with a high specificity. Many studies have shown hypermethylation of RASSF $1 A$ in cancer may have several clinical utilities. These include its use as a diagnostic marker, as a marker for early detection or patient prognosis, as a predictive marker in benign growths from 'at risk' patients or even as a marker for resistance to some treatments.

\subsection{Diagnostic marker}

For lung cancer surgical intervention is more successful when tumours are detected early and are still re- sectable. One strategy for early detection could be the screening of populations at risk such as smokers. The lifetime risk of never smokers developing lung cancer is $1 \times 10^{-4}$ whereas for current and former chronic smokers the yearly risk is $0.3 \%$ [11]. Bronchial aspirates from smokers and never smokers with lung cancer showed frequencies of RASSF $1 A$ methylation of $21 \%$ and $1 \%$ respectively. Amongst smokers the frequency of methylation was $10 \%$ for $\leqslant 30$ pack years smoked versus $26 \%$ for $>30$ pack years smoked [103]. Methylation was also significantly associated with the number of pack years smoked during the lifetime $(p \leqslant 0.05)$. Another population at risk of developing lung cancer are lung cancer survivors $(6.0 \%$ risk per patient year, 5 -year survival of $60 \%$ [11]). A recent investigation of RASSF $1 A$ methylation in plasma and sputum revealed a frequency of $7 \%$ in current and former smokers whereas in lung cancer survivors it was $25 \%(p \leqslant 0.01)$ [11]. Using a panel of four genes commonly methylated in cancer, including RASSF $1 A$, methylation of at least one gene could be detected in the upper aerodigestive tract from $48 \%$ of current smokers without cancer [138]. This study included samples obtained from bronchial brushes, bronchoalveolar lavage and oropharyngeal brushes with RASSF1A methylation detected in $6 \%, 5 \%$ and $2 \%$ of the samples respectively. In a separate study of sputum from current and former smokers some of whom later developed cancer RASSF1A methylation could be detected [53]. RASSF1A methy- 
lation has also been detected in the tumour and corresponding bronchoalveolar lavages in $29 \%(5 / 17)$ of methylated lung cancer cases and in combination with 5 other tumour-related genes could diagnose lung cancer in $68 \%$ (21/31) of patients [112]. These data suggest regular screening for RASSF $1 A$ methylation in sputum, bronchoalveolar lavages and serum from populations at risk, particularly smokers and lung cancer survivors, may enable earlier detection of lung cancer and the reduction of lung cancer mortality. Ramirez et al. [97] showed 34\% (17/51) NSCLC tumours showed RASSF 1A methylation with concomitant methylation observed in the corresponding serum.

In a recent report, methylation analysis of a panel of just 3 genes (RASSF1A, APC and DAPK1) was sufficient to differentiate normal and tumour tissue in $94 \%$ of breast cancer cases. Dulaimi et al. [31] also showed $76 \%$ of corresponding serum DNA was also positive for methylation illustrating the potential sensitivity of these methylation markers in early detection of breast cancer [31]. Furthermore, in breast cancer patients where RASSF 1A methylation is undetectable in plasma, methylation may be detected in tumour DNA eluted from the surface of erythrocytes and leukocytes suggesting a further measure to increase sensitivity of detection [100]. Alternatively, breast cancer has also been detected in nipple aspirate fluid in $82 \%$ (18/22) cases including ductal carcinoma in situ and stage I cancer by $\mathrm{CpG}$ island hypermethylation [66]. Analysis of urine DNA represents a simple method for kidney and bladder cancer detection. Investigation of 45 urothelial cancer patients and 12 normal healthy individuals using a panel of just three genes (RASSF1A, APC and $\mathrm{p} 14^{\mathrm{ARF}}$ ) gave a diagnostic coverage of $100 \%$, sensitivity of $87 \%$ and specificity of $100 \%$ [33]. More importantly, methylation analysis identified 16 cases that had negative cytology. In a different study RASSF $1 A$ methylation was detected in the urine of $50 \%(7 / 14)$ bladder cancer patients, but not in normal control samples. This study also showed methylation analysis of urine DNA was more sensitive than conventional cytology especially for low-grade tumours [15]. Battagli et al. [10] found at least one of a panel of six genes ( $V H L$, $p 16^{\mathrm{INK} 4 \mathrm{~A}}, p 14^{\mathrm{ARF}}, A P C, R A S S F 1 A$ and TIMP3) were methylated in all 50 kidney tumours investigated. Furthermore, the same pattern of methylation was observed in corresponding urine DNA in 88\% (44/50) of cases, including $27 / 30$ cases of stage I disease. The diagnostic potential of DNA hypermethylation has also been explored in ovarian cancer. In one study the use of 6 genes (RASSF1A, BRCA1, APC, DAPK1, p14 ${ }^{\mathrm{ARF}}$ and $\left.p 16^{\text {INK4A }}\right)$ gave $100 \%$ diagnostic coverage (50/50 tumours) with RASSF1A methylation detected in $50 \%$ cases. Furthermore RASSF1A methylation was detected in patient serum from $84 \%(21 / 25)$ methylated tumour cases including several stage I tumours. Of the 50 tumours investigated serum or peritoneal fluid was positive for methylation in $88 \%$ of cases thus offering a much greater diagnostic sensitivity than conventional cytology. In some cases methylation was detected in the serum of patients negative for the CA-125 serum marker [57]. In general however, DNA hypermethylation would provide a very powerful adjunct to conventional diagnostic methods such as cytology and histology. For example, a study of RASSF $1 A, p 16^{\text {INK4A }}$ and $A P C$ methylation in bronchial aspirates showed that cytology, quantitative MSP and histology could detect lung cancer in 44\% (37/85), 53\% (45/85) and 59\% (50/85) of cases respectively. When combined however diagnostic sensitivity extended to $81 \%$ (69/85) of patients [103].

A novel approach of detecting endometrial cancer was recently described with the use of DNA collected from tampons [41]. In this study, hypermethylation of 3 or more of 5 candidate genes, including RASSF 1A, was a significant indicator of endometrial cancer $(p=0.001)$ with a sensitivity and specificity of $100 \%$ and $97.2 \%$ respectively. Those patients without endometrial cancer that showed hypermethylation of 3 or more genes were shown to have cervical cancer, endometrium polyps or fibroids. RASSF $1 A$ methylation was also detectable in $57 \%(16 / 28)$ glioma tumours and in 50\% (14/28) of corresponding patient serum [97]. However, some other studies have shown limited success in the detection of RASSF1A methylation in serum. For example, methylation was detected in $65 \%$ (34/52) of Hodgkin's lymphoma tumours but in only $2 / 22$ corresponding serum [89]. Methylation of $C D H 1, p 16^{\mathrm{INK} 4 \mathrm{~A}}, D A P K 1$ and $p 15^{\mathrm{INK} 4 \mathrm{~B}}$ could be detected in $46 \%, 42 \%, 20 \%$ and $20 \%$ of plasma from NPC patients respectively, yet only $5 \%$ showed RASSF $1 A$ methylation [127]. In a further study of NPC RASSF 1A methylation was detected in $67 \%$ (20/30) of tumour samples and in $3 \%$ of corresponding plasma. However, in nasopharyngeal swabs and mouth and throat rinsings methylation was detected at frequencies of $33 \%$ and $37 \%$ respectively illustrating the importance of selecting the correct body fluid [16]. Taken together, these studies show that RASSF1A methylation can be detected in a range of body fluids from cancer patients and offers an exciting new approach to cancer diagnosis. The sensitivity of methylation assays in these body fluids compares favourably with conventional diagnostic methods. 


\subsection{Predictive}

Several studies have illustrated the use of RASSF 1A methylation in benign growths or hyperplastic lesions as a means of predicting cancer risk. In benign breast tissues from unaffected women at high-risk for breast cancer RASSF1A methylation was found in $70 \%$ of samples, but in only $29 \%$ of samples from women at low/intermediate risk. Demonstrating that in benign breast epithelium $R A S S F 1 A$ promoter methylation is associated with epidemiological markers of increased breast cancer risk. In particular, biopsies from women with a previous history of benign breast growths were statistically more likely to have RASSF1A methylation [75]. RASSF1A methylation is also prevalent in breast epithelial hyperplasia, papilloma samples and ductal carcinoma in situ but not in normal breast tissues [53,72]. Early prediction of prostate cancer may also be possible since 19-28\% of benign prostate hyperplasia (BPH) samples also show methylation [9, 106] with some studies describing up to $100 \%$ in tumours and BPH samples $[59,68]$. Precancerous intestinal metaplasia lesions may also be useful for predicting gastric cancer risk since a subgroup show RASSF 1A methylation [110]. This suggests that RASSF $1 A$ methylation in benign growths or hyperplastic lesions often indicates an increased risk of some forms of cancer which may be detected at the earliest stages with regular surveillance.

\subsection{Prognosis}

For some cancers an association between RASSF $1 A$ methylation and adverse patient survival has been observed. Burbee et al. [12] found that NSCLC patients with RASSF 1A methylation had a mean overall survival of 37 months compared with 52 months for patients without $R A S S F 1 A$ methylation $(p=0.0463)$ [12]. In lung adenocarcinoma RASSF1A methylation was significantly associated with vascular invasion, pleural involvement, poor tumour differentiation, decreased patient survival time and allelic loss at 3 p21.3 [111]. Since all tumours investigated were stage I this study suggests RASSF 1A methylation would provide a powerful marker for patient prognosis at an early stage of lung adenocarcinoma development. In a study of 119 well-characterised NSCLC tumours RASSF1A methylation was also more frequently observed in poorlydifferentiated tumours $(50 \%)$ than in tumours of moderate $(26 \%)$ or high $(0 \%)$ differentiation $(p=0.04)$. More importantly, methylation of $p 16^{\text {INK4A }}$ was associated with stage I/II disease whereas RASSF1A methylation was associated with stage IIIA disease [123]. This contradicts the earlier report by Tomizawa et al. [111] and suggests that RASSF1A methylation occurs during NSCLC progression whereas $p 16^{\mathrm{INK} 4 \mathrm{~A}}$ inactivation occurs in the early stages of lung cancer development. Wang et al. [123] also show $p 16^{\mathrm{INK} 4 \mathrm{~A}}$ and RASSF $1 A$ methylation were powerful prognostic indicators. Patients with stage I/II tumours containing $p 16^{\mathrm{INK} 4 \mathrm{~A}}$ methylation had a significantly poorer 5 year survival rate compared to those without $p 16^{\mathrm{INK} 4 \mathrm{~A}}$ methylation. However, RASSF $1 A$, and $p 16^{\mathrm{INK} 4 \mathrm{~A}}$, methylation in stage IIIA tumours were profound indicators of poor survival. All 11 stage IIIA patients with methylation of both genes died within 3 years postsurgery, whereas 21 (62\%) with methylation of either $p 16^{\mathrm{INK} 4 \mathrm{~A}}$ or RASSF1A died within 5 years and only $5(29 \%)$ with methylation of neither died within 6.5 years $(p=0.0001)$. RASSF $1 A$ methylation remained a very strong prognostic indicator irrespective of whether patients had received adjuvant radiotherapy [123]. In contrast to this, a more recent study of 116 cases of NSCLC showed that RASSF1A methylation was not related to poor prognosis, including tumour stage, recurrence, lymphatic permeation and smoking duration [19]. However, a significant association between RASSF 1A methylation, age at which smoking began (below 19 years) and decreased NSCLC patient survival time has been observed [63]. Interestingly, another study showed that earlier recurrence of lung cancer (but not tumour grade, stage, histological type or patient survival) is associated with RASSF IA methylation [37]. With regular surveillance this may allow early detection of recurrent tumours. However, additional studies will be required to clarify the prognostic value of RASSF 1A methylation in lung cancer. In prostate cancer RASSF $1 A$ methylation status may be informative of disease progression. Tumours with a high Gleason score or high serum prostate-specific antigen (both features of poor prognosis and advanced prostate cancer) showed a significantly higher frequency of RASSF 1A methylation $[61,78,83]$. However, some studies show that hypermethylation of GSTP1, APC and PTGS2 in prostate cancer is more informative of prognosis $[9$, 59] whereas RASSF 1A methylation was only associated with advanced stage [59]. Many studies have shown that RASSF 1A methylation, as well as methylation of some other tumour-related genes, occurs significantly more frequently in tumours of a higher-grade, later stage or in invasive or metastatic tumours. This has been shown in many types of cancer including 
breast cancer, bladder cancer, salivary adenoid cystic carcinoma, glioma, pituitary adenomas, pancreatic endocrine tumours and gastric cancer indicating RASSF 1A methylation may be used as a marker for tumour progression and metastasis $[13,43,49,70,76,82$, 84,95]. Methylation of MGMT, RASSF $1 A$ and DAPK1 is also significantly associated with progression from primary melanoma to metastatic melanoma [55]. Many other studies provide further evidence that RASSF $1 A$ methylation is a marker for disease progression. For example, a study of transitional cell carcinomas (comprising 116 bladder and 164 upper-tract tumours) revealed a significantly higher frequency of RASSF $1 A$ methylation in poorly-differentiated $(p=0.017)$ and more rapidly progressing tumours (0.0076) [14]. Mortality was also higher in tumours with RASSF1A methylation ( $p=0.018)$. Methylated RASSF1A and/or APC DNA in serum from breast cancer patients is strongly associated with metastasis, tumour size and increased relative risk for death [87]. A total of $11 \%(7 / 66)$ of patients with methylation of RASSF $1 A$ or APC died compared with $53 \%(10 / 19)$ of patients with methylation of both ( $p=0.001)$. In summary, RASSF1A methylation in tumour tissue and corresponding body fluids often correlates with advanced tumour stage and grade, metastasis, poor tumour differentiation and adverse survival.

\subsection{Drug resistance}

Testicular nonseminoma germ cell tumours (NSGCT) are particularly sensitive to cisplatin-based chemotherapy. However, 20-30\% of metastatic tumours acquire resistance to such therapy. A recent study showed hypermethylation of RASSFIA and HICl was much more frequent in cisplatin resistant versus cisplatin sensitive NSGCT [65]. Interestingly the frequency of both RASSFIA and HICl methylation increased following each regimen of cisplatin chemotherapy. Very recently RASSF $1 A$ methylation in the serum of breast cancer patients was identified as a surrogate marker for the monitoring of response to adjuvant tamoxifen treatment [42]. Persistence of RASSF1A methylation post-surgery and throughout treatment indicated resistance to tamoxifen whereas loss of methylation indicated a response. Thus, RASSF1A methylation may offer a marker for cisplatin and tamoxifen resistance in some tumours and could be monitored throughout the course of treatment.

\section{Conclusion}

Whilst global hypomethylation is a characteristic of many cancers, the specific hypermethylation of the $\mathrm{CpG}$ islands associated with certain tumour suppressor genes may be exploitable for the generation of assays to determine clinical risk. However a current problem with methylation as a biomarker is its potential lack of specificity, for example in the colon the genome becomes increasingly methylated as an individual ages and whilst this may reflect the increased risk of colon cancer experienced by older people, it may also confound techniques that rely on an absence of methylation to predict reduced risk. The use of panels of carefully chosen markers specific for the tumour type and taking into account the demographics of the population to be tested will be an essential prerequisite to successful clinical application of these assays. Regardless of the role of DNA hypermethylation in cancer these epigenetic changes will become useful in the clinic as diagnostic or prognostic markers. The value of using methylation of RASSF $1 A$ and other tumour-related genes as cancer biomarkers depends on whether these markers could offer earlier detection, greater reliability and sensitivity or be more informative of patient prognosis when compared with existing screening strategies. As discussed this appears the case for at least some cancers. Furthermore, as an adjunct to existing cancer detection methods screening for hypermethylation would provide a non-invasive, rapid and cost effective means of increasing the sensitivity and reliability of cancer diagnosis from a range of readily available body fluids. When compared with existing screening strategies methylation analysis can provide a more informative and powerful prognostic indicator with a greater level of sensitivity for some cancers. However, the use of hypermethylation as a cancer biomarker requires a panel of several carefully chosen genes that offer the greatest diagnostic coverage and prognostic information for a given cancer. Given the frequencies of RASSF1A methylation, the broad spectrum of tumour types in which this occurs and its potential prognostic value, RASSF 1A should be considered for inclusion in any such panel of candidate genes.

\section{Acknowledgments}

Research in F. LATIF laboratory funded in part by Breast Cancer Campaign, Cancer Research UK and Birmingham Children's Hospital Research Foundation. 


\section{References}

[1] A. Agathanggelou, I. Bieche, J. Ahmed-Choudhury, B. Nicke, R. Dammann, S. Baksh, B.N. Gao, J.D. Minna, J. Downward, E.R. Maher and F. Latif, Identification of novel gene expression targets for the Ras association domain family 1 (RASSF1A) tumor suppressor gene in non-small cell lung cancer and neuroblastoma, Cancer Res 63 (2003), 53445351.

[2] A. Agathanggelou, W.N. Cooper and F. Latif, Role of the ras-association domain family 1 tumor suppressor gene in human cancers, Cancer Res 65 (2005), 3497-3508.

[3] A. Agathanggelou, S. Honorio, D.P. Macartney, A. Martinez, A. Dallol, J. Radar, P. Fullwood, A. Chauhan, R. Walker, J.A. Shaw, S. Hosoe, M.I. Lerman, J.D. Minna, E.R. Maher and F. Latif, Methylation associated inactivation of RASSF1A from region 3p21.3 in lung, breast and ovarian tumours, Oncogene 20 (2001), 1509-1518.

[4] K. Akino, M. Toyota, H. Suzuki, H. Mita, Y. Sasaki, M. OheToyota, J.P.J. Issa, Y. Hinoda, K. Imai and T. Tokino, The Ras effector RASSF2 is a novel tumor-suppressor gene in human colorectal cancer, Gastroenterology 129 (2005), 156-169.

[5] D. Astuti, A. Agathanggelou, S. Honorio, A. Dallol, T. Martinsson, P. Kogner, C. Cummins, H.P.H. Neumann, R. Voutilainen, P. Dahia, C. Eng, E.R. Maher and F. Latif, RASSF1A promoter region $\mathrm{CpG}$ island hypermethylation in phaeochromocytomas and neuroblastoma tumours, Oncogene 20 (2001), 7573-7577.

[6] S. Baksh, S. Tommasi, S. Fenton, V.C. Yu, L.M. Martins, G.P. Pfeifer, F. Latif, J. Downward and B.G. Neel, The tumor suppressor RASSF1A and MAP-1 link death receptor signaling to bax conformational change and cell death, Molecular Cell 18 (2005), 637-650.

[7] C. Balana, J.L. Ramirez, M. Taron, Y. Roussos, A. Ariza, R. Ballester, C. Sarries, P. Mendez, J.J. Sanchez and R. Rosell, O-6-methyl-guanine-DNA methyltransferase methylation in serum and tumor DNA predicts response to 1,3bis(2-chloroethyl)-1- nitrosourea but not to temozolamide plus cisplatin in glioblastoma multiforme, Clin Cancer Res 9 (2003), 1461-1468.

[8] B. Banelli, I. Gelvi, A. Di Vinci, P. Scaruffi, I. Casciano, G. Allemanni, S. Bonassi, G.P. Tonini and M. Romani, Distinct $\mathrm{CpG}$ methylation profiles characterize different clinical groups of neuroblastic tumors, Oncogene 24 (2005), 56195628 .

[9] P.J. Bastian, J. Ellinger, A. Wellmann, N. Wernert, L.C. Heukamp, S.C. Muller and A. von Ruecker, Diagnostic and prognostic information in prostate cancer with the help of a small set of hypermethylated gene loci, Clin Cancer Res $\mathbf{1 1}$ (2005), 4097-4106.

[10] C. Battagli, R.G. Uzzo, E. Dulaimi, I. Ibanez de Caceres, R. Krassenstein, T. Al-Saleem, R.E. Greenberg and P. Cairns, Promoter hypermethylation of tumor suppressor genes in urine from kidney cancer patients, Cancer Res 63 (2003), 8695-8699.

[11] S.A. Belinsky, D.M. Klinge, J.D. Dekker, M.W. Smith, T.J. Bocklage, F.D. Gilliland, R.E. Crowell, D.D. Karp, C.A. Stidley and M.A. Picchi, Gene promoter methylation in plasma and sputum increases with lung cancer risk, Clin Cancer Res 11 (2005), 6505-6511.

[12] D.G. Burbee, E. Forgacs, S. Zochbauer-Muller, L. Shivakumar, K. Fong, B.N. Gao, D. Randle, M. Kondo, A. Virmani, S. Bader, Y. Sekido, F. Latif, S. Milchgrub, S. Toyooka, A.F. Gazdar, M.I. Lerman, E. Zabarovsky, M. White and
J.D. Minna, Epigenetic inactivation of RASSF1A in lung and breast cancers and malignant phenotype suppression, $J$ Natl Cancer Inst 93 (2001), 691-699.

[13] D.S. Byun, M.G. Lee, K.S. Chae, B.G. Ryu and S.G. Chi, Frequent epigenetic inactivation of RASSF1A by aberrant promoter hypermethylation in human gastric adenocarcinoma, Cancer Res 61 (2001), 7034-7038.

[14] J.W.F. Catto, A.R. Azzouzi, I. Rehman, K.M. Feeley, S.S. Cross, N. Amira, G. Fromont, M. Sibony, O. Cussenot, M. Meuth and F.C. Hamdy, Promoter hypermethylation is associated with tumor location, stage, and subsequent progression in transitional cell carcinoma, J Clin Oncol 23 (2005), 2903-2910.

[15] M.W.Y. Chan, L.W. Chan, N.L.S. Tang, K.W. Lo, J.H.M. Tong, A.W.H. Chan, H.Y. Cheung, W.S. Wong, P.S.F. Chan, F.M.M. Lai and K.F. To, Frequent hypermethylation of promoter region of RASSF1A in tumor tissues and voided urine of urinary bladder cancer patients, Int J Cancer 104 (2003), 611-616.

[16] H.W. Chang, A. Chan, D.L.W. Kwong, W.I. Wei, J.S.T. Sham and A.P.W. Yuen, Evaluation of hypermethylated tumor suppressor genes as tumor markers in mouth and throat rinsing fluid, nasopharyngeal swab and peripheral blood of nasopharygeal carcinoma patient, Int J Cancer 105 (2003), 851-855.

[17] J.D. Chen, W.O. Lui, M.D. Vos, G.J. Clark, M. Takahashi, J. Schoumans, S.K. Khoo, D. Petillo, T. Lavery, J. Sugimura, D. Astuti, C. Zhang, S. Kagawa, E.R. Maher, C. Larsson, A.S. Alberts, H.O. Kanayama and B.T. Teh, The t $(1 ; 3)$ breakpointspanning involved in clear cell renal cell genes LSAMP and NORE1 are carcinomas, Cancer Cell 4 (2003), 405-413.

[18] Y.J. Chen, Q.B. Tang and S.Q. Zou, Inactivation of RASSF1A, the tumor suppressor gene at 3 p21.3 in extrahepatic cholangiocarcinoma, World J Gastroenterol 11 (2005), 1333-1338.

[19] N. Choi, D.S. Son, I. Song, H.S. Lee, Y.S. Lim, M.S. Song, D.S. Lim, J. Lee, H. Kim and J. Kim, RASSF1A is not appropriate as an early detection marker or a prognostic marker for non-small cell lung cancer, Int J Cancer 115 (2005), $575-581$.

[20] L.S. Chow, C.W. Lam, S.Y. Chan, S.W. Tsao, K.F. To, S.F. Tong, W.K. Hung, R. Dammann, D.P. Huang and K.W. Lo, Identification of RASSF1A modulated genes in nasopharyngeal carcinoma, Oncogene (2005), In press.

[21] L.S.N. Chow, K.W. Lo, J. Kwong, K.F. To, K.S. Tsang, C.W. Lam, R. Dammann and D.P. Huang, RASSF1A is a target tumor suppressor from $3 \mathrm{p} 21.3$ in nasopharyngeal carcinoma, Int J Cancer 109 (2004), 839-847.

[22] L.S.N. Chow, K.W. Lo, J. Kwong, A.Y.H. Wong and D.P. Huang, Aberrant methylation of RASSF4/AD037 in nasopharyngeal carcinoma, Oncol Rep 12 (2004), 781-787.

[23] K.W. Choy, T.C. Lee, K.F. Cheung, D.S.P. Fan, K.W. Lo, K.L. Beaverson, D.H. Abramson, D.S.C. Lam, C.B.O. Yu and C.P. Pang, Clinical implications of promoter hypermethylation in RASSF1A and MGMT in retinoblastomal, Neoplasia 7 (2005), 200-206.

[24] Y. Cohen, G. Singer, O. Lavie, S.M. Dong, U. Beller and D. Sidransky, The RASSF1A tumor suppressor gene is commonly inactivated in adenocarcinoma of the uterine cervix, Clin Cancer Res 9 (2003), 2981-2984.

[25] A. Dallol, A. Agathanggelou, S.L. Fenton, J. AhmedChoudhury, L. Hesson, M.D. Vos, G.J. Clark, J. Downward, E.R. Maher and F. Latif, RASSFIA interacts with 
microtubule-associated proteins and modulates microtubule dynamics, Cancer Res 64 (2004), 4112-4116.

[26] R. Dammann, C. Li, J.H. Yoon, P.L. Chin, S. Bates and G.P. Pfeifer, Epigenetic inactivation of a RAS association domain family protein from the lung tumour suppressor locus $3 \mathrm{p} 21.3$, Nature Genet 25 (2000), 315-319.

[27] R. Dammann, U. Schagdarsurengin, L.M. Liu, N. Otto, O. Gimm, H. Dralle, B. Boehm, G.P. Pfeifer and C. Hoang$\mathrm{Vu}$, Frequent RASSF1A promoter hypermethylation and $\mathrm{K}$ ras mutations in pancreatic carcinoma, Oncogene 22 (2003), 3806-3812.

[28] R. Dammann, T. Takahashi and G.P. Pfeifer, The CpG island of the novel tumor suppressor gene RASSF1A is intensely methylated in primary small cell lung carcinomas, Oncogene 20 (2001), 3563-3567.

[29] S.M. Dong, D.I. Sun, N.E. Benoit, I. Kuzmin, M.I. Lerman and D. Sidransky, Epigenetic inactivation of RASSF1A in head and neck cancer, Clin Cancer Res 9 (2003), 3635-3640.

[30] K. Dreijerink, E. Braga, I. Kuzmin, L. Geil, F.M. Duh, D. Angeloni, B. Zbar, M.I. Lerman, E.J. Stanbridge, J.D. Minna, A. Protopopov, J.F. Li, V. Kashuba, G. Klein and E.R. Zabarovsky, The candidate tumor suppressor gene, RASSF1A, from human chromosome 3 p21.3 is involved in kidney tumorigenesis, Proc Natl Acad Sci USA 98 (2001), 7504-7509.

[31] E. Dulaimi, J. Hillinck, I. Ibanez de Caceres, T. Al-Saleem and P. Cairns, Tumor suppressor gene promoter hypermethylation in serum of breast cancer patients, Clin Cancer Res $\mathbf{1 0}$ (2004), 6189-6193.

[32] E. Dulaimi, I. Ibanez de Caceres, R.G. Uzzo, T. Al-Saleem, R.E. Greenberg, T.J. Polascik, J.S. Babb, W.E. Grizzle and P. Cairns, Promoter hypermethylation profile of kidney cancer, Clin Cancer Res 10 (2004), 3972-3979.

[33] E. Dulaimi, R.G. Uzzo, R.E. Greenberg, T. Al-Saleem and P. Cairns, Detection of bladder cancer in urine by a tumor suppressor gene hypermethylation panel, Clin Cancer Res 10 (2004), 1887-1893.

[34] C.A. Eads, K.D. Danenberg, K. Kawakami, L.B. Saltz, C. Blake, D. Shibata, P.V. Danenberg and P.W. Laird, MethyLight: a high-throughput assay to measure DNA methylation, Nucleic Acids Res 28 (2000), E32.

[35] K. Eckfeld, L. Hesson, M.D. Vos, I. Bieche, F. Latif and G.J. Clark, RASSF4/AD037 is a potential ras effector/tumor suppressor of the RASSF family, Cancer Res 64 (2004), 8688-8693.

[36] M. Ehrlich, G.C. Jiang, E. Fiala, J.S. Dome, M.C. Yu, T.I. Long, B. Youn, O.S. Sohn, M. Widschwendter, G.E. Tomlinson, M. Chintagumpala, M. Champagne, D. Parham, G.N. Liang, K. Malik and P.W. Laird, Hypomethylation and hypermethylation of DNA in Wilms tumors, Oncogene 21 (2002), 6694-6702.

[37] H. Endoh, Y. Yatabe, S. Shmizu, K. Tajima, H. Kuwano, T. Takahashi and T. Mitsudomi, RASSF1A gene inactivation in non-small cell lung cancer and its clinical implication, Int J Cancer 106 (2003), 45-51.

[38] M. Endoh, G. Tamura, T. Honda, N. Homma, M. Terashima, S. Nishizuka and T. Motoyama, RASSF2, a potential tumour suppressor, is silenced by $\mathrm{CpG}$ island hypermethylation in gastric cancer, Br J Cancer 93 (2005), 1395-1399.

[39] L. Fajas, C. Paul, O. Zugasti, L. Le Cam, J. Polanowska, E. Fabbrizio, R. Medema, M.L. Vignais and C. Sardet, $\mathrm{pRB}$ binds to and modulates the transrepressing activity of the E1A-regulated transcription factor p120(E4F), Proc Natl Acad Sci USA 97 (2000), 7738-7743.
[40] S.L. Fenton, A. Dallol, A. Agathanggelou, L. Hesson, J. Ahmed-Choudhury, S. Baksh, C. Sardet, R. Dammann, J.D. Minna, J. Downward, E.R. Maher and F. Latif, Identification of the E1A-regulated transcription factor p120(E4F) as an interacting partner of the RASSF1A candidate tumor suppressor gene, Cancer Res 64 (2004), 102-107.

[41] H. Fiegl, C. Gattringer, A. Widschwendter, A. Schneitter, A. Ramoni, D. Sarlay, I. Gaugg, G. Goebel, H.M. Muller, E. Mueller-Holzner, C. Marth and M. Widschwendter, Methylated DNA collected by tampons - A new tool to detect endometrial cancer, Cancer Epidemiol Biomarkers Prev 13 (2004), 882-888.

[42] H. Fiegl, S. Millinger, E. Mueller-Holzner, C. Marth, C. Ensinger, A. Berger, H. Klocker, G. Goebel and M. Widschwendter, Circulating tumor-specific DNA: A marker for monitoring efficacy of adjuvant therapy in cancer patients, Cancer Res 65 (2005), 1141-1145.

[43] M.G. Friedrich, D.J. Weisenberger, J.C. Cheng, S. Chandrasoma, K.D. Siegmund, M.L. Gonzalgo, M.I. Toma, H. Huland, C. Yoo, Y.C. Tsai, P.W. Nichols, B.H. Bochner, P.A. Jones and G.N. Liang, Detection of methylated apoptosisassociated genes in urine sediments of bladder cancer patients, Clin Cancer Res 10 (2004), 7457-7465.

[44] O. Galm, S. Wilop, J. Reichelt, E. Jost, G. Gehbauer, J.G. Herman and R. Osieka, DNA methylation changes in multiple myeloma, Leukemia 18 (2004), 1687-1692.

[45] D.W. Hamilton, M.E. Lusher, J.C. Lindsey, D.W. Ellison and S.C. Clifford, Epigenetic inactivation of the RASSF1A tumour suppressor gene in ependymoma, Cancer Lett 227 (2005), 75-81.

[46] K. Harada, S. Toyooka, A. Maitra, R. Maruyama, K.O. Toyooka, C.F. Timmons, G.E. Tomlinson, D. Mastrangelo, R.J. Hay, J.D. Minna and A.F. Gazdar, Aberrant promoter methylation and silencing of the RASSF1A gene in pediatric tumors and cell lines, Oncogene 21 (2002), 4345-4349.

[47] M. Hasegawa, H.H. Nelson, E. Peters, E. Ringstrom, M. Posner and K.T. Kelsey, Patterns of gene promoter methylation in squamous cell cancer of the head and neck, Oncogene 21 (2002), 4231-4236.

[48] J.G. Herman, J.R. Graff, S. Myohanen, B.D. Nelkin and S.B. Baylin, Methylation-specific PCR: A novel PCR assay for methylation status of CpG islands, Proc Natl Acad Sci USA 93 (1996), 9821-9826.

[49] L. Hesson, I. Bieche, D. Krex, E. Criniere, K. Hoang-Xuan, E.R. Maher and F. Latif, Frequent epigenetic inactivation of RASSF1A and BLU genes located within the critical 3p21.3 region in gliomas, Oncogene 23 (2004), 2408-2419.

[50] L. Hesson, A. Dallol, J.D. Minna, E.R. Maher and F. Latif, NORE1A, a homologue of RASSF1A tumour suppressor gene is inactivated in human cancers, Oncogene 22 (2003), 947-954.

[51] L.B. Hesson, R. Wilson, D. Morton, C. Adams, M. Walker, E.R. Maher and F. Latif, CpG island promoter hypermethylation of a novel Ras-effector gene RASSF2A is an early event in colon carcinogenesis and correlates inversely with K-ras mutations, Oncogene 24 (2005), 3987-3994.

[52] R.P. Hogg, S. Honorio, A. Martinez, A. Agathanggelou, A. Dallol, P. Fullwood, R. Weichselbaum, M.J. Kuo, E.R. Maher and F. Latif, Frequent $3 p$ allele loss and epigenetic inactivation of the RASSF1A tumour suppressor gene from region 3 p21.3 in head and neck squamous cell carcinoma, Eur $J$ Cancer 38 (2002), 1585-1592.

[53] S. Honorio, A. Agathanggelou, M. Schuermann, W. Pankow, P. Viacava, E.R. Maher and F. Latif, Detection of RASSF1A 
aberrant promoter hypermethylation in sputum from chronic smokers and ductal carcinoma in situ from breast cancer patients, Oncogene 22 (2003), 147-150.

[54] S. Honorio, A. Agathanggelou, N. Wernert, M. Rothe, E.R. Maher and F. Latif, Frequent epigenetic inactivation of the RASSF1A tumour suppressor gene in testicular tumours and distinct methylation profiles of seminoma and nonseminoma testicular germ cell tumours, Oncogene 22 (2003), 461-466.

[55] D.S.B. Hoon, M. Spugnardi, C. Kuo, S.K. Huang, D.L. Morton and B. Taback, Profiling epigenetic inactivation of tumor suppressor genes in tumors and plasma from cutaneous melanoma patients, Oncogene 23 (2004), 4014-4022.

[56] K. Horiguchi, Y. Tomizawa, M. Tosaka, S. Ishiuchi, H. Kurihara, M. Mori and N. Saito, Epigenetic inactivation of RASSF1A candidate tumor suppressor gene at $3 \mathrm{p} 21.3$ in brain tumors, Oncogene 22 (2003), 7862-7865.

[57] I. Ibanez de Caceres, C. Battagli, M. Esteller, J.G. Herman, E. Dulaimi, M.I. Edelson, C. Bergman, H. Ehya, B.L. Eisenberg and P. Cairns, Tumor cell-specific BRCA1 and RASSF1A hypermethylation in serum, plasma, and peritoneal fluid from ovarian cancer patients, Cancer Res 64 (2004), 6476-6481.

[58] M. Irimia, M.F. Fraga, M. Sanchez-Cespedes and M. Esteller, $\mathrm{CpG}$ island promoter hypermethylation of the Ras-effector gene NORE1A occurs in the context of a wild-type K-ras in lung cancer, Oncogene 23 (2004), 8695-8699.

[59] C. Jeronimo, R. Henrique, M.O. Hoque, E. Mambo, F.R. Ribeiro, G. Varzim, J. Oliveira, M.R. Teixeira, C. Lopes and D. Sidransky, A quantitative promoter methylation profile of prostate cancer, Clin Cancer Res 10 (2004), 8472-8478.

[60] G.H. Kang, S. Lee, W.H. Kim, H.W. Lee, J.C. Kim, M.G. Rhyu and J.Y. Ro, Epstein-Barr virus-positive gastric carcinoma demonstrates frequent aberrant methylation of multiple genes and constitutes $\mathrm{CpG}$ island methylator phenotypepositive gastric carcinoma, Am J Pathol 160 (2002), 787794.

[61] G.H. Kang, S. Lee, H.J. Lee and K.S. Hwang, Aberrant CpG island hypermethylation of multiple genes in prostate cancer and prostatic intraepithelial neoplasia, J Pathol 202 (2004), 233-240.

[62] A. Khokhlatchev, S. Rabizadeh, R. Xavier, M. Nedwidek, T. Chen, X.F. Zhang, B. Seed and J. Avruch, Identification of a novel Ras-regulated proapoptotic pathway, Curr Biol 12 (2002), 253-265.

[63] D.H. Kim, J.S. Kim, Y.I. Ji, Y.M. Shim, H. Kim, J.H. Han and J. Park, Hypermethylation of RASSF1A promoter is associated with the age at starting smoking and a poor prognosis in primary non-small cell lung cancer, Cancer Res 63 (2003), 3743-3746.

[64] S. Koul, J. Houldsworth, M.M. Mansukhani, A. Donadio, J.M. McKiernan, V.E. Reuter, G.J. Bosl, R.S. Chaganti and V.V. Murty, Characteristic promoter hypermethylation signatures in male germ cell tumors, Mol Cancer 1 (2002), 8.

[65] S. Koul, J.M. McKiernan, G. Narayan, J. Houldsworth, J. Bacik, D.L. Dobrzynski, A.M. Assaad, M. Mansukhani, V.E. Reuter, G.J. Bosl, R.S. Chaganti and V.V. Murty, Role of promoter hypermethylation in Cisplatin treatment response of male germ cell tumors, Mol Cancer 3 (2004), 16.

[66] R. Krassenstein, E. Sauter, E. Dulaimi, C. Battagli, H. Ehya, A. Klein-Szanto and P. Cairns, Detection of breast cancer in nipple aspirate fluid by $\mathrm{CpG}$ island hypermethylation, Clin Cancer Res 10 (2004), 28-32.

[67] T. Kuroki, F. Trapasso, S. Yendamuri, A. Matsuyama, H. Alder, M. Mori and C.M. Croce, Allele loss and promoter hypermethylation of VHL, RAR-beta, RASSF1A, and FHIT tumor suppressor genes on chromosome $3 p$ in esophageal squamous cell carcinoma, Cancer Res 63 (2003), 3724-3728.

[68] I. Kuzmin, J.W. Gillespie, A. Protopopov, L. Geil, K. Dreijerink, Y.F. Yang, C.D. Vocke, F.M. Duh, E. Zabarovsky, J.D. Minna, J.S. Rhim, M.R. Emmert-Buck, W.M. Linehan and M.I. Lerman, The RASSF1A tumor suppressor gene is inactivated in prostate tumors and suppresses growth of prostate carcinoma cells, Cancer Res 62 (2002), 3498-3502.

[69] I. Kuzmin, L.M. Liu, R. Dammann, L. Geil, E.J. Stanbridge, S.P. Wilczynski, M.I. Lerman and G.P. Pfeifer, Inactivation of RAS association domain family 1 A gene in cervical carcinomas and the role of human papillomavirus infection, Cancer Res 63 (2003), 1888-1893.

[70] M.G. Lee, H.Y. Kim, D.S. Byun, S.J. Lee, C.H. Lee, J.I. Kim, S.G. Chang and S.G. Chi, Frequent epigenetic inactivation of RASSF1A in human bladder carcinoma, Cancer Res 61 (2001), 6688-6692.

[71] S. Lee, K.S. Hwang, H.J. Lee, J.S. Kim and G.H. Kang, Aberrant $\mathrm{CpG}$ island hypermethylation of multiple genes in colorectal neoplasia, Lab Invest 84 (2004), 884-893.

[72] U. Lehmann, F. Langer, H. Feist, S. Glockner, B. Hasemeier and H. Kreipe, Quantitative assessment of promoter hypermethylation during breast cancer development, Am J Pathol 160 (2002), 605-612.

[73] S.A. Leon, B. Shapiro, D.M. Sklaroff and M.J. Yaros, Free DNA in Serum of Cancer-Patients and Effect of Therapy, Cancer Res 37 (1977), 646-650.

[74] M.I. Lerman and J.D. Minna, for The International Lung Cancer Chromosome 3p21.3 Tumour Suppressor Gene Consortium, The 630-kb lung cancer homozygous deletion region on human chromosome 3p21.3: Identification and evaluation of the resident candidate tumor suppressor genes, Cancer Res 60 (2000), 6116-6133.

[75] C.M. Lewis, L.R. Cler, D.W. Bu, S. Zochbauer-Muller, S. Milchgrub, E.Z. Naftalis, A.M. Leitch, J.D. Minna and D.M. Euhus, Promoter hypermethylation in benign breast epithelium in relation to predicted breast cancer risk, Clin Cancer Res 11 (2005), 166-172.

[76] J. Li, A. El-Naggar and L. Mao, Promoter methylation of p16(INK4), RASSF1A, and DAPK is frequent in salivary adenoid cystic carcinoma, Cancer 104 (2005), 771-776.

[77] L.M. Liu, S. Tommasi, D.H. Lee, R. Dammann and G.P. Pfeifer, Control of microtubule stability by the RASSF1A tumor suppressor, Oncogene 22 (2003), 8125-8136.

[78] L.M. Liu, J.H. Yoon, R. Dammann and G.P. Pfeifer, Frequent hypermethylation of the RASSF1A gene in prostate cancer, Oncogene 21 (2002), 6835-6840.

[79] K.W. Lo, J. Kwong, A.B.Y. Hui, S.Y.Y. Chan, K.F. To, S.C. Chan, L.S.N. Chow, P.M.L. Teo, P.J. Johnson and D.P. Huang, High frequency of promoter hypermethylation of RASSF1A in nasopharyngeal carcinoma, Cancer Res 61 (2001), 38773881.

[80] M.E. Lusher, J.C. Lindsey, F. Latif, A.D.J. Pearson, D.W. Ellison and S.C. Clifford, Biallelic epigenetic inactivation of the RASSF1A tumor suppressor gene in medulloblastoma development, Cancer Res 62 (2002), 5906-5911.

[81] S.I. Maruya, J.P.J. Issa, R.S. Weber, D.I. Rosenthal, J.C. Haviland, R. Lotan and A.K. El-Naggar, Differential methylation status of tumor-associated genes in head and neck squamous carcinoma: Incidence and potential implications, Clin Cancer Res 10 (2004), 3825-3830.

[82] R. Maruyama, S. Toyooka, K.O. Toyooka, K. Harada, A.K. Virmani, S. Zochbauer-Muller, A.J. Farinas, F. Vakar-Lopez, J.D. Minna, A. Sagalowsky, B. Czerniak and A.F. Gazdar, 
Aberrant promoter methylation profile of bladder cancer and its relationship to clinicopathological features, Cancer Res 61 (2001), 8659-8663.

[83] R. Maruyama, S. Toyooka, K.O. Toyooka, A.K. Virmani, S. Zochbauer-Muller, A.J. Farinas, J.D. Minna, J. McConnell, E.P. Frenkel and A.F. Gazdar, Aberrant promoter methylation profile of prostate cancers and its relationship to clinicopathological features, Clin Cancer Res 8 (2002), 514-519.

[84] J. Mehrotra, M. Vali, M. McVeigh, S.L. Kominsky, M.J. Fackler, J. Lahti-Domenici, K. Polyak, N. Sacchi, E. GarrettMayer, P. Argani and S. Sukumar, Very high frequency of hypermethylated genes in breast cancer metastasis to the bone, brain, and lung, Clin Cancer Res 10 (2004), 3104-3109.

[85] C. Morrissey, A. Martinez, M. Zatyka, A. Agathanggelou, S. Honorio, D. Astuti, N.V. Morgan, H. Moch, F.M. Richards, T. Kishida, M. Yao, P. Schraml, F. Latif and E.R. Maher, Epigenetic inactivation of the RASSF1A 3p21.3 tumor suppressor gene in both clear cell and papillary renal cell carcinoma, Cancer Res 61 (2001), 7277-7281.

[86] J. Muhlisch, A. Schwering, M. Grotzer, G.H. Vince, W. Roggendorf, C. Hagemann, N. Sorensen, C.H. Rickert, N. Osada, H. Jurgens and M.C. Fruhwald, Epigenetic repression of RASSF1A but not CASP8 in supratentorial PNET (sPNET) and atypical teratoid/rhabdoid tumors (AT/RT) of childhood, Oncogene (2005), in press.

[87] H.M. Muller, A. Widschwendter, H. Fiegl, L. Ivarsson, G. Goebel, E. Perkmann, C. Marth and M. Widschwendter, DNA methylation in serum of breast cancer patients: An independent prognostic marker, Cancer Res 63 (2003), 76417645 .

[88] H.M. Muller and M. Widschwendter, Methylated DNA as a possible screening marker for neoplastic disease in several body fluids, Expert Review of Molecular Diagnostics 3 (2003), 443-458.

[89] P.G. Murray, G.H. Qiu, L. Fu, E.R. Waites, G. Srivastava, D. Heys, A. Agathanggelou, F. Latif, R.G. Grundy, J.R. Mann, J. Starczynski, J. Crocker, S.E. Parkes, R.F. Ambinder, L.S. Young and Q. Tao, Frequent epigenetic inactivation of the RASSF1A tumor suppressor gene in Hodgkin's lymphoma, Oncogene 23 (2004), 1326-1331.

[90] M.H.L. Ng, K.M. Lau, W.S. Wong, K.W. To, S.H. Cheng, K.S. Tsang, N.P.H. Chan, B.C.S. Kho, K.W. Lo, J.H.M. Tong, C.W. Lam and J.C.W. Chan, Alterations of RAS signalling in Chinese multiple myeloma patients: absent BRAF and rare RAS mutations, but frequent inactivation of RASSF1A by transcriptional silencing or expression of a non-functional variant transcript, Br J Haematol 123 (2003), 637-645.

[91] K. Okami, A. Sakai, J. Onuki, T. Hamano, M. Iida and M. Takahashi, Promoter hypermethylation of tumor-associated genes in head and neck cancer, Nippon Jibiinkoka Gakkai Kaiho 108 (2005), 207-213.

[92] S. Ortiz-Vega, A. Khokhlatchev, M. Nedwidek, X.F. Zhang, R. Dammann, G.P. Pfeifer and J. Avruch, The putative tumor suppressor RASSF1A homodimerizes and heterodimerizes with the Ras-GTP binding protein Nore1, Oncogene $\mathbf{2 1}$ (2002), 1381-1390.

[93] Z.G. Pan, V.I. Kashuba, X.Q. Liu, J.Y. Shao, R.H. Zhang, J.H. Jiang, C. Guo, E. Zabarovsky, I. Ernberg and Y.X. Zeng, High Frequency Somatic Mutations in RASSF1A in Nasopharyngeal Carcinoma, Cancer Biol Ther 4 (2005), 1116-1122.

[94] M. Praskova, A. Khoklatchev, S. Ortiz-Vega and J. Avruch, Regulation of the MST1 kinase by autophosphorylation, by the growth inhibitory proteins, RASSF1 and NORE1, and by Ras, Biochem J 381 (2004), 453-462.
[95] Z.R. Qian, T. Sano, K. Yoshimoto, A. Ishizuka, N. Mizusawa, H. Horiguchi, M. Hirokawa and S.L. Asa, Inactivation of RASSF1A tumor suppressor gene by aberrant promoter hypermethylation in human pituitary adenomas, Lab Invest 85 (2005), 464-473.

[96] S. Rabizadeh, R.J. Xavier, K. Ishiguro, J. Bernabeortiz, M. Lopez-Ilasaca, A. Khokhlatchev, P. Mollahan, G.P. Pfeifer, J. Avruch and B. Seed, The scaffold protein CNK1 interacts with the tumor suppressor RASSF1A and augments RASSF1A-induced cell death, J Biol Chem 279 (2004), 29247-29254.

[97] J.L. Ramirez, M. Taron, C. Balana, C. Sarries, P. Mendez, I. de Aguirre, L. Nunez, B. Roig, C. Queralt, M. Botia and R. Rosell, Serum DNA as a tool for cancer patient management, Rocz Akad Med Bialymst 48 (2003), 34-41.

[98] A. Rathi, A.K. Virmani, J.O. Schorge, K.J. Elias, R. Maruyama, J.D. Minna, S.C. Mok, L. Girard, D.A. Fishman and A.F. Gazdar, Methylation profiles of sporadic ovarian tumors and nonmalignant ovaries from high-risk women, Clin Cancer Res 8 (2002), 3324-3331.

[99] H. Rizos, E. Diefenbach, P. Badhwar, S. Woodruff, T.M. Becker, R.J. Rooney, and R.F. Kefford, Association of p14(ARF) with the p120(E4F) transcriptional repressor enhances cell cycle inhibition, J Biol Chem 278 (2003), 49814989

[100] E.Y. Rykova, P.P. Laktionov, T.E. Skvortsova, A.V. Starikov, N.P. Kuznetsova and V.V. Vlassov, Extracellular DNA in breast cancer - Cell-surface-bound, tumor- derived extracellular DNA in blood of patients with breast cancer and nonmalignant tumors, Annals of the New York Academy of Sciences 1022 (2004), 217-220.

[101] P. Sandy, M. Gostissa, V. Fogal, L. De Cecco, K. Szalay, R.J. Rooney, C. Schneider and G. Del Sal, p53 is involved in the p120E4F-mediated growth arrest, Oncogene 19 (2000), $188-199$.

[102] U. Schagdarsurengin, O. Gimm, C. Hoang-Vu, H. Dralle, G.P. Pfeifer and R. Dammann, Frequent epigenetic silencing of the CpG island promoter of RASSF1A in thyroid carcinoma, Cancer Res 62 (2002), 3698-3701.

[103] V. Schmiemann, A. Bocking, M. Kazimirek, A.S.C. Onofre, H.E. Gabbert, R. Kappes, C.D. Gerharz and H.J. Grote, Methylation assay for the diagnosis of lung cancer on bronchial aspirates: A cohort study, Clin Cancer Res 11 (2005), 7728-7734.

[104] S. Seidl, J. Ackermann, H. Kaufmann, A. Keck, T. Nosslinger, C.C. Zielinski, J. Drach and S. ZochbauerMuller, DNA-methylation analysis identifies the E-cadherin gene as a potential marker of disease progression in patients with monoclonal gammopathies, Cancer 100 (2004), 25982606.

[105] L. Shivakumar, J. Minna, T. Sakamaki, R. Pestell and M.A. White, The RASSF1A tumor suppressor blocks cell cycle progression and inhibits cyclin D1 accumulation, Mol Cell Biol 22 (2002), 4309-4318.

[106] R. Singal, L. Ferdinand, I.M. Reis and J.J. Schlesselman, Methylation of multiple genes in prostate cancer and the relationship with clinicopathological features of disease, Oncol Rep 12 (2004), 631-637.

[107] M.S. Song, S.J. Song, N.G. Ayad, J.S. Chang, J.H. Lee, H.K. Hong, H. Lee, N. Choi, J. Kim, H. Kim, J.W. Kim, E.J. Choi, M.W. Kirschner and D.S. Lim, The tumour suppressor RASSF1A regulates mitosis by inhibiting the APC-Cdc20 complex, Nat Cell Biol 6 (2004), 129-137. 
[108] M. Spugnardi, S. Tommasi, R. Dammann, G.P. Pfeifer and D.S.B. Hoon, Epigenetic inactivation of RAS Association Domain Family Protein 1 (RASSF1A) in malignant cutaneous melanoma, Cancer Res 63 (2003), 1639-1643.

[109] K.O. Tan, K.M.L. Tan, S.L. Chan, K.S.Y. Yee, M. Bevort, K.C. Ang and V.C. Yu, MAP-1, a novel proapoptotic protein containing a BH3-like motif that associates with Bax through its Bcl-2 homology domains, J Biol Chem 276 (2001), 28022807.

[110] K.F. To, W.K. Leung, T.L. Lee, J. Yu, J.H.M. Tong, M.W.Y. Chan, E.K.W. Ng, S.C.S. Chung and J.J.Y. Sung, Promoter hypermethylation of tumor-related genes in gastric intestinal metaplasia of patients with and without gastric cancer, Int $J$ Cancer 102 (2002), 623-628.

[111] Y. Tomizawa, T. Kohno, H. Kondo, A. Otsuka, M. Nishioka, T. Niki, T. Yamada, A. Maeshima, K. Yoshimura, R. Saito, J.D. Minna and J. Yokota, Clinicopathological significance of epigenetic inactivation of RASSF1A at $3 \mathrm{p} 21.3$ in stage I lung adenocarcinoma, Clin Cancer Res 8 (2002), 2362-2368.

[112] O. Topaloglu, M.O. Hoque, Y. Tokumaru, J. Lee, E. Ratovitski, D. Sidransky and C.S. Moon, Detection of promoter hypermethylation of multiple genes in the tumor and bronchoalveolar lavage of patients with lung cancer, Clin Cancer Res 10 (2004), 2284-2288.

[113] S. Toyooka, H.I. Pass, N. Shivapurkar, Y. Fukuyama, R. Maruyama, K.O. Toyooka, M. Gilcrease, A. Farinas, J.D. Minna and A.F. Gazdar, Aberrant methylation and simian virus 40 tag sequences in malignant mesothelioma, Cancer Res 61 (2001), 5727-5730.

[114] S. Toyooka, K.O. Toyooka, R. Maruyama, A.K. Virmani, L. Girard, K. Miyajima, K. Harada, Y. Ariyoshi, T. Takahashi, K. Sugio, E. Brambilla, M. Gilcrease, J.D. Minna and A.F. Gazdar, DNA methylation profiles of lung tumors, $\mathrm{Mol}$ Cancer Ther 1 (2001), 61-67.

[115] T. Tozawa, G. Tamura, T. Honda, S. Nawata, W. Kimura, N. Makino, S. Kawata, T. Sugai, T. Suto and T. Motoyama, Promoter hypermethylation of DAP-kinase is associated with poor survival in primary biliary tract carcinoma patients, Cancer Sci 95 (2004), 736-740.

[116] B.N. Trinh, T.I. Long and P.W. Laird, DNA methylation analysis by MethyLight technology, Methods 25 (2001), 456462.

[117] M. van Engeland, G. Roemen, M. Brink, M.M.M. Paachen, M.P. Weijenberg, A.P. de Bruine, J.W. Arends, P.A. van den Brandt, A. de Goeij and J.G. Herman, K-ras mutations and RASSF1A promoter methylation in colorectal cancer, Oncogene 21 (2002), 3792-3795.

[118] D. Vavvas, X. Li, J. Avruch and X.F. Zhang, Identification of Nore1 as a potential Ras effector, J Biol Chem 273 (1998), 5439-5442.

[119] M.D. Vos, C.A. Ellis, C. Elam, A.S. Ulku, B.J. Taylor and G.J. Clark, RASSF2 is a novel K-Ras-specific effector and potential tumor suppressor, J Biol Chem 278 (2003), 2804528051.

[120] M.D. Vos, A. Martinez, C. Elam, A. Dallol, B.J. Taylor, F. Latif and G.J. Clark, A role for the RASSF1A tumor suppressor in the regulation of tubulin polymerization and genomic stability, Cancer Res 64 (2004), 4244-4250.

[121] M.D. Vos, A. Martinez, C.A. Ellis, T. Vallecorsa and G.J. Clark, The pro-apoptotic Ras effector Nore1 may serve as a Ras- regulated tumor suppressor in the lung, $J$ Biol Chem 278 (2003), 21938-21943.

[122] K.J. Wagner, W.N. Cooper, R.G. Grundy, G. Caldwell, C. Jones, R.B. Wadey, D. Morton, P.N. Schofield, W. Reik, F.
Latif and E.R. Maher, Frequent RASSF1A tumour suppressor gene promoter methylation in Wilms' tumour and colorectal cancer, Oncogene 21 (2002), 7277-7282.

[123] J. Wang, J.J. Lee, L. Wang, D.D. Liu, C. Lu, Y.H. Fan, W.K. Hong and L. Mao, Value of p16(INK4a) and RASSF1A promoter hypermethylation in prognosis of patients with resectable non-small cell lung cancer, Clin Cancer Res $\mathbf{1 0}$ (2004), 6119-6125.

[124] M. Widschwendter and P.A. Jones, The potential prognostic, predictive, and therapeutic values of DNA methylation in cancer (Commentary re: J. Kwong et al., Promoter hypermethylation of multiple genes in nasopharyngeal carcinoma. Clin Cancer Res, 8: 131-137, 2002, and H.-Z. Zou et al., Detection of aberrant p16 methylation in the serum of colorectal cancer patients. Clin Cancer Res, 8: 188-191, 2002), Clin Cancer Res 8 (2002), 17-21.

[125] P.A. Wingo, L.A.G. Ries, G.A. Giovino, D.S. Miller, H.M. Rosenberg, D.R. Shopland, M.J. Thun and B.K. Edwards, Annual report to the nation on the status of cancer, 19731996, with a special section on lung cancer and tobacco smoking, J Natl Cancer Inst 91 (1999), 675-690.

[126] N. Wong, L. Li, K. Tsang, P.B.S. Lai, K.F. To and P.J. Johnson, Frequent loss of chromosome $3 p$ and hypermethylation of RASSF1A in cholangiocarcinoma, J Hepatol 37 (2002), 633-639.

[127] T.S. Wong, D.L.W. Kwong, J.S.T. Sham, W.I. Wei, Y.L. Kwong and A.P.W. Yuen, Quantitative plasma hypermethylated DNA markers of undifferentiated nasopharyngeal carcinoma, Clin Cancer Res 10 (2004), 2401-2406.

[128] M.Z. Xing, Y. Cohen, E. Mambo, G. Tallini, R. Udelsman, P.W. Ladenson and D. Sidransky, Early occurrence of RASSF1A hypermethylation and its mutual exclusion with BRAF mutation in thyroid tumorigenesis, Cancer Res 64 (2004), 1664-1668.

[129] Z.G. Xiong and P.W. Laird, COBRA: A sensitive and quantitative DNA methylation assay, Nucleic Acids Research 25 (1997), 2532-2534.

[130] S. Yamaguchi, H. Kato, T. Miyazaki, M. Sohda, H. Kimura, M. Ide, T. Asao and H. Kuwano, RASSF1A gene promoter methylation in esophageal cancer specimens, Diseases of the Esophagus 18 (2005), 253-256.

[131] B. Yang, M.G. House, M.Z. Guo, J.G. Herman and D.P. Clark, Promoter methylation profiles of tumor suppressor genes in intrahepatic and extrahepatic cholangiocarcinoma, Mod Pathol 18 (2005), 412-420.

[132] J.H. Yoon, R. Damman and G.P. Pfeifer, Hypermethylation of the $\mathrm{CpG}$ island of the RASSF1A gene in ovarian and renal cell carcinomas, Int J Cancer 94 (2001), 212-217.

[133] J. Yu, M. Ni, J. Xu, H.Y. Zhang, B.M. Gao, J.R. Gu, J.G. Chen, L.S. Zhang, M.C. Wu, S.S. Zhen and J.D. Zhu, Methylation profiling of twenty promoter-CpG islands of genes which may contribute to hepatocellular carcinogenesis, $B M C$ Cancer 2 (2002), art. no. 29.

[134] M.Y. Yu, J.H.M. Tong, P.K.S. Chan, T.L. Lee, M.W.Y. Chan, A.W.H. Chan, K.W. Lo and K.F. To, Hypermethylation of the tumor suppressor gene Rassf1a and frequent concomitant loss of heterozygosity at $3 \mathrm{p} 21$ in cervical cancers, Int $J$ Cancer 105 (2003), 204-209.

[135] J. Zhang, C.R. Martins, Z.B. Fansler, K.L. Roemer, E.A. Kincaid, K.S. Gustafson, D.F. Heitjan and D.P. Clark, DNAmethylation in anal intraepithelial lesions and anal squamous cell carcinoma, Clin Cancer Res 11 (2005), 6544-6549.

[136] Y.J. Zhang, H. Ahsan, Y. Chen, R.M. Lunn, L.Y. Wang, S.Y. Chen, P.H. Lee, C.J. Chen and R.M. Santella, High frequency 
of promoter hypermethylation of RASSF1A and p16 and its relationship to aflatoxin B-1-DNA adduct levels in human hepatocellular carcinoma, Mol Carcinog 35 (2002), 85-92.

[137] S. Zhong, W. Yeo, M.W. Tang, N. Wong, P.B.S. Lai and P.J. Johnson, Intensive hypermethylation of the $\mathrm{CpG}$ island of Ras association domain family $1 \mathrm{~A}$ in hepatitis B virusassociated hepatocellular carcinomas, Clin Cancer Res 9 (2003), 3376-3382.
[138] S. Zochbauer-Muller, S. Lam, S. Toyooka, A.K. Virmani, K.O. Toyooka, S. Seidl, J.D. Minna and A.F. Gazdar, Aberrant methylation of multiple genes in the upper aerodigestive tract epithelium of heavy smokers, Int J Cancer 107 (2003), 612-616. 


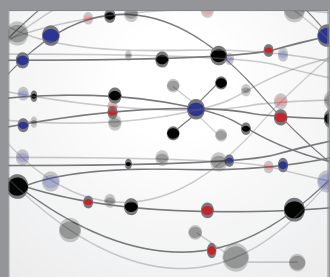

The Scientific World Journal
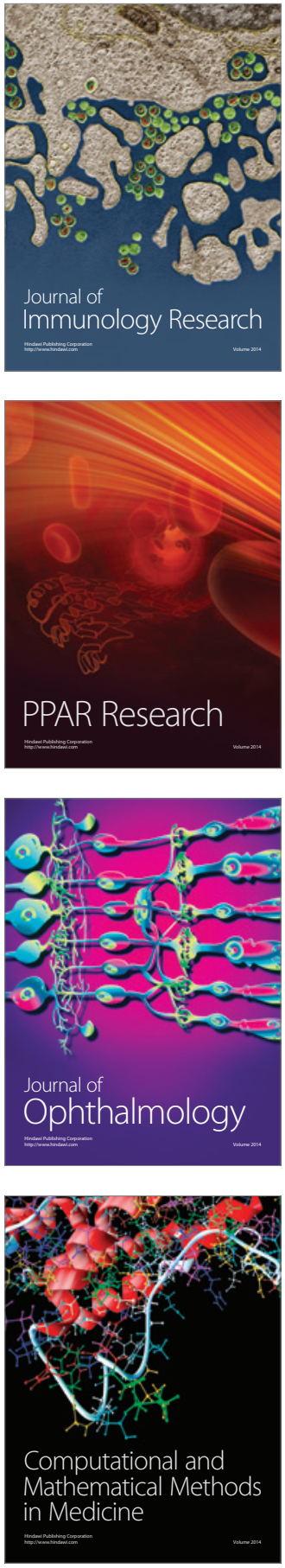

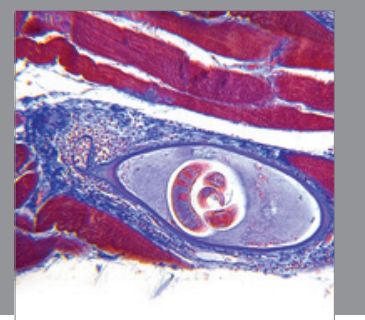

Gastroenterology

Research and Practice
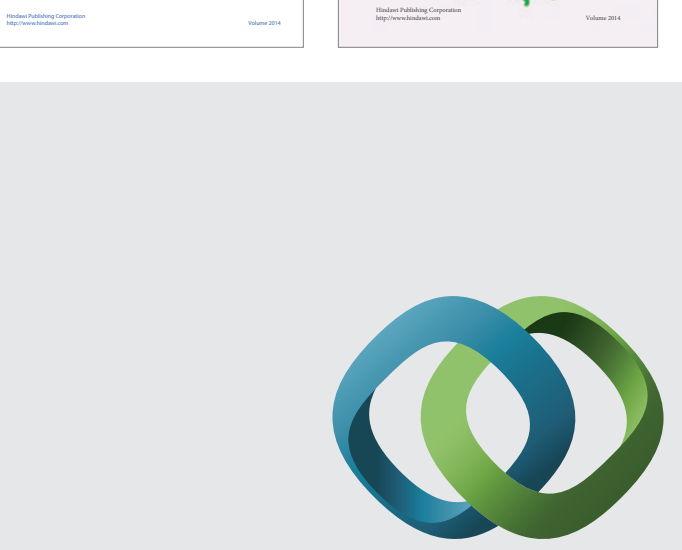

\section{Hindawi}

Submit your manuscripts at

http://www.hindawi.com
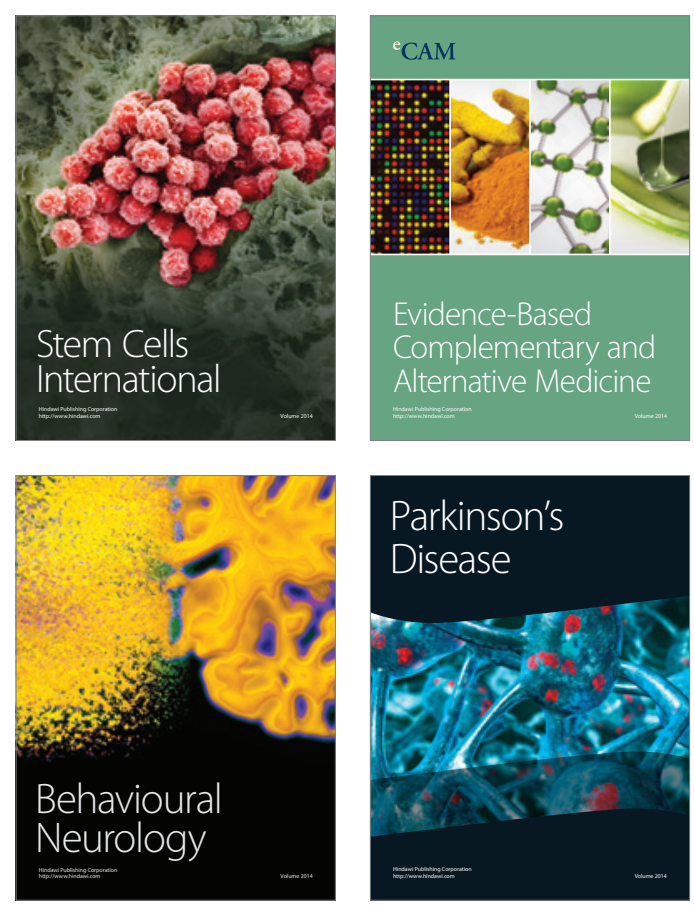

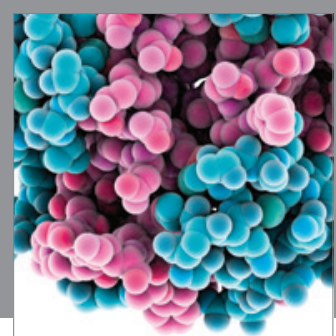

Journal of
Diabetes Research

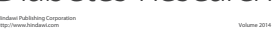

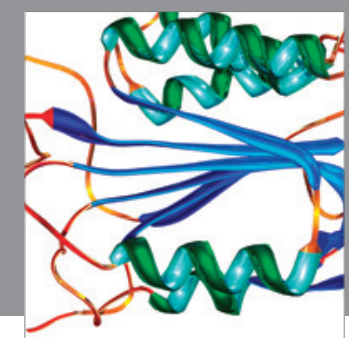

Disease Markers
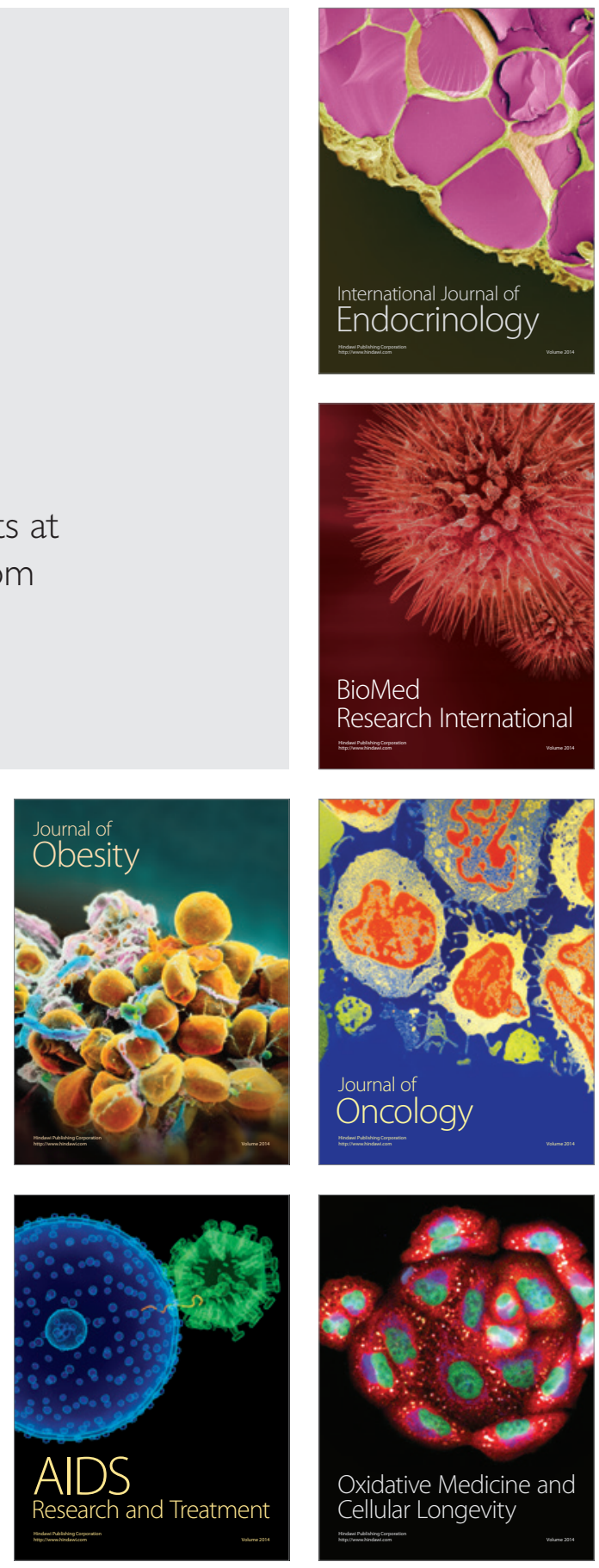